\title{
TERAPI MUSIK DANGDUT TERHADAP DEPRESI PADA ORANG DENGAN SKIZOFRENIA DI RSJD DR.ARIF ZAINUDIN SURAKARTA
}

\author{
Irna Kartina, Adit Kurniawan, Febriana Sartikasari, Innez Karunia Mustikarani \\ Fakultas Ilmu Kesehatan, Universitas Kusuma Husada Surakarta \\ Jl. Jaya Wijaya No. 11 Kadipiro, Banjarsari, Surakarta, Jawa Tengah, Indonesia \\ irnakartina@ukh.ac.id
}

\begin{abstract}
Abstrak
Schizoprenia merupakan jenis gangguan dalam Kesehatan jiwa yang sering terdata di pendududk Indonesia, sekitar $70 \%$ dari pasien yang di rawat di dalm Rumah sakit Jiwa adalah orang dengan Schizoprenia (ODS). Peningkatan dan penambahan angka kesakitan pada OD terus meningkat, denagn gangguan dan gejala yang beragam, salah satunya dari gejala positif yang dialami adalah depresi, Penelitian bermaksud untuk menginvestigasi dampak terapi musik dangdut yaitu musik yang familiar dengan warga Indonesia pada tingkat depresi ODS yang ada di RSJ. AFIF ZAINUDIN. Surakarta, Jawa Tengah. Indoensia. Adapun Metode yang digunakana dalam metode pre-experiment dengan jumlah sampel yang memenuhi kriteria adalah 11 respondent. Hasil analisis data didapatkan distribusi data nilai rata-rata post test sesi pertama adalah 17.00 dan post test sesi kelima adalah 6.00. nilai $\mathrm{z}=-4.322$. sedangkan hasil uji Mann Whitney menunjukkan bahwa nilai signifikansi yang tergambar dengan $p$ value 0.000 . Kesimpulan yang bisa ditarik dari penelitian terapi music memiliki dampak positif terhadap depresi di RSJD Dr. Arif Zainudin Surakarta.
\end{abstract}

Kata kunci : ODS, Terapi musik, Terapi musik dangdut, Depresi.

Abstract

Schizophrenia is one of mental disorder which has negative effect on human brain and its cognitive function, perception, emotional, and behavior. In Indonesia the schizophrenia lead to the big number , almost touch $70 \%$ in population of people with mental illness. This study will investigate the impact of Dangdut Music Therapy among them, which were hospitalized in RSJD dr.Arif Zainudin Surakarta. This study used quantitative method with pre-experiment (without control) approach with pre-posttest applied, with total sampling 11 people with schizophrenia. The therapy were given in 4 time of intervention. Finding of this study was there were significant dissimilarity between pre-test and post test mean, P Value was 0.000. In conclusion, the Dangdut Music Therapy could be used as an alternative to treat depression on people with schizophrenia.

Keywords : Dangdut Music Therapy, Schizophrenia, Music Therapy, Depression.

\section{PENDAHULUAN}

Berdasarkan data yang diperoleh oleh RISKESDAS (2018), didapatkan bahwa setiap provinsi di indonesia mengalami peningkatan jumlah keluarga yang terkait dengan gangguan jiwa. skizofrenia/ psikosis. Peningkatna tersebut berkisar dari 5-10 \% dalam setiap provinsi. Provinsi Jawa Tengah memiliki urutan ke 5 setelah Bali, DIY, NTB dan Aceh, dari data tersebut dapat dilihat bahwa jawa tenagh memiliki angka yang cukup besar dan keadaan yang serius terkait jumlah orang dnegan gangguan Jiwa yang menderita skizofrenia (ODGJ/ODS)

Data yang terhimpun dari Rumah Sakit Jiwa Daerah Surakarta sendiri memiliki jumlah yang cukup tinggi pada 3 tahun terdata. Jumlah ODS pada data 2014 adalah 1.559 orang, sedangkan 2015 meningkat lebih dari 500 ODS menjadi 2.136 dan pada 2016 sempat mengalami penurunan jumlah namun tetap dalngka diatas 2000 jiwa yaitu 2.034 orang. Data terakhir pada Januari-April 2017 terdapat 43-

Corresponding author:

Irna Kartina

Irnakartina@ukh.ac.id 
77\%. Jumlah ODS yang terdaftar dan dirawat inap di RSJD dr Arif Zainudin, Surakarta.

Provinsi Jawa tengah sejauh ini telah melakukan beberapa upaya, salah satu yang disampaikan adalah program pandawa Lima (Pendidikan Kesehatan Jiwa Libatkan Mahasiswa). Namun beberapa upaya yang telah dicanangkan belum bisa dikatakan berhasil dengan berkaca pada angka kejadian pasung yang masih tinggi, yaitu sebesar (RISKESDAS, 2018). Angka kesakitan pada kesehatan jiwa masih menjadi hal yang serius untuk diperhatikan, kerjasama yang luas yang mengikutkan pengambil keputusan, institusi pendidikan kesehatan, organisasi profesi keseahtan, Lembaga sosial, tenaga kesehatan, dan peranserta masyarakat untuk mendukung kegiatan promotif, preventif, kuratif dan rehabilitatif sanagt dibutuhkan (Setiawan, 2018).

Pada ranah Rumah Sakit sendiri upaya program yang dilakukan selain sesuai dengan program utama pelayanan asuhan keperawatan, maka program inovasi yang menyesuaikan dengan kulturat dan kondisi ODS pun disesuaikan, salah satunya modifikasi bentuk TAK dnegan berbagai kegiatannyang interaktif. Namun, belum ditemukan program inovasi yang melibatkan terapi musik menjadi program tetap yang utama. Bila ditinjau dari literatur yang telah tercatat, terdapat beberpa penelitian yang menyampaikan dampak positif dari terapi musik untuk ODGJ/ODS. Terapi musik dipercaya mampu menurunkan tingkat kekambuhan pada ODS (Purnama, 2016), mempengaruhi tanda dan gejala pada ODS dengan halusinasi (Lewerissa,2019) serta mampu menurunkan gangguan prilaku apati (Taroreh, 2004). Adapun penelitian ini ingin melakukan investigasi terhadap dampak penerapan musik dangdut terhadap depresi pada penderita skizofrenia.

\section{METODE PENELITIAN}

Penelitiaan pre-ekperimental dimana subjek penelitian di rekrut dengan menggunakan purposive sampling, dengan syarat yang telah ditentukan oleh peneliti yaitu ; dirawat dengan diagnosis medis Schizofrenia, memiliki gejala postif : depresi, telah dirawat di ruang kronik atau rehabilitasi, tidak dalam ruang isolasi, serta mendapat izin oleh perawat enanggung jawab untuk melakukan proses terapi selama perjalanan penelitian.

Penelitian diproses dengan melakukan izin penelitian kepada pihak Ruangan rawat di RSJD Dr. Arif Zainudin Surakarta, kemudian melakukan rekrut subjek berdasar kriteria dan melakukan terapi musik dangdut selama 4 sesi dengan menjadikan terapi sebagai kegiatan harian selama 4 hari. Sebelum melakukan TAK dengan menggunakan musik dangdut, setiap ODS telah diberikan pretest berupa skala pengukuran tingkat depresi denagn menggunakan zung self rating depression scale. Skala depresi juga di ukur setelah intervensi terapi musik..

Sampel dalam penelitian ini berjumlah 11 orang dengan Skizofrenia yang memiliki gejala depresi aktif, Tindakan dilakukan selama 50 menit per sesi, Setelah semua rangkaian terapi dan pengambilan data, penelitian dilanjutkan dengan proses Analisa data telah dilakukan dengan menggunakan SPSS, adapun jenis analisa data yang dipakai adalah wilcoxson dan Mannw-Withney.

\section{HASIL}

Hasil uji stastistik didapatkan setelah uji wilcoxon menunjukkan signifikan $p$ value dari keempat sesi adalah $\mathrm{p}<0,05$. 
Tabel 1

\begin{tabular}{ccc}
\multicolumn{3}{c}{ Hasil Analisa Bivariat : Wilcoxon } \\
\hline Sesi & Mean & P value \\
\hline Pre dan post test 1 & 2.50 & 0.046 \\
Pre dan post test 2 & 3.00 & 0.025 \\
Pre dan post test 3 & 3.50 & 0.014 \\
Pre dan post test 4 & 3.50 & 0.014 \\
\hline
\end{tabular}

Berdasarkan tabel 1didapatkan nilai p memenuhi kriteria Ha diterima, maka dapat dikatakan bahwa ada perbedaan antara hasil tingkat depresi sebelum intervensi dan setelah intervensi disetiap sesi terapi musik dangdut.

Tabel 2

Hasil Analisa Mann-Whitney

\begin{tabular}{ccc}
\multicolumn{3}{c}{ Hasil Analisa Mann-Whitney } \\
\hline Kelompok & Mean & P value \\
\hline Pre test sesi 1 & 17.00 & 0.000 \\
Post test sesi 4 & 6.00 &
\end{tabular}

$P$ Value pada hasil Uji Mann-Whitney yang telah dilakukan menunjukan $P$ Value $<0,05$, yang dimana dapat diambil kesimpulan ilmiah data penolakan pada Ho, yang berarti terapi musik dangdut ini memiliki pengaruh terhadap tingkat depresi pada kelompok eksperimen yang telah dilakukan selama 4 sesi.

\section{PEMBAHASAN}

\section{Perbedaan Tingkat Depresi setelah dilakukan Terapi Musik Dangdut}

Tingkat depresi pada ODS pada 4 sesi terapi mengalami perubahan, dapat dilihat ada perbedaan nilai mean yang berbeda anata setiap sesi nya, Adapun bila di telaaah lebih mendalam pada nilai $P$ value setiap sesi memiliki nilai yang kurnag dari $\mathrm{P}$ Value 0,5 , nilai tersebut mennjukkan ada perbedaaan secara signifikan tentang tingkatan depresi pada ODS disetiap sesinya, meski bila diperhatikan secara meluas, semakin berulang sesi terapi yang diberikan nilai mean pun semakin meningkat.

Peningkatan nilai mean saat semakin banyak frekuensi terapi dilakukan bisa diambil sebagai pertimbangan bila nanti akan mengimplementasikan terapi musik dangdut pada ODS dengan keadaan yang sama, beat atau kecepatan irama musik dangdut adalah lebih cepat dibanding dengan irama musik klasik, sehingga pada penelitian-penelitian sebelumnya pada musik klasik memiliki ritme mean yang cenderung menurun atau berkebalikan dari hasil penelitian ini, seperti pada penelitian Marzuki (2018) pada lansia yaitu menurunkan tingkat depresi dari $66,7 \%$ menjadi 61,6\%. Pada penelitian lain dengan jenis musik keroncong yang memiliki beat lebih rendah juga memiliki pola yang tidak serupa, namun mampu memberikan pengaruh penurunan pada tingkat depresi dari sedang menjadi ringan pada lansia (Purbowinoto, 2011).

Dengan melihat beberapa penelitian sebelumnya yang memiliki ritme yang berbeda namun memiliki hasil pengaruh pada penurunan tingkat depresi, dapat disimpulkan bahwa setiap sesi dari terpai musik dangdut terhadap depresi memiliki pengaruh, hal ini di perkuat dengan nilai PValue yang memenuhi syarat sebuah tindakan memiliki nilai statistik.

\section{Pengaruh Terapi Musik Dangdut kepada Tingkat Depresi}

Pada penelitian ini subjek penlitian hanya bisa direkrut 11 responden, angka yang tidak terlalu kecil untuk bisa menjadi pertimbangan sebuah terapi dapat di adopsi dalam Tindakan keperawatan. Berdasarkan Tabel.2, dapat di maknai perubahan antara keadaan tingkat depresi pada ODS sebelum diberikan terapi selama 4 sesi mengalami cukup tinggi yaitu memiliki mena 17,00 , sedangkan setelah diberikan terapi musik dangdut selama 4 
sesi mengalami penurunan hingga 6,00 , hal ini semakin diperkuat dnegan nilai $\mathrm{P}$ Value 0,000 , yang menyampaikan hasil penelitian ini terbuksi secara signifikan mampu menurunkan tinglkat depresi pada ODS di ruang rawat RSJD Dr, Arif Zainudin Surakarta.

Perubahan nilai mean yang tajam ini ,didukung dari hasil temuan Lerik (2005) yang dilakukan pada tingkat depresi, begitu juga dengan penelitian yang dilakukan pada lansia yang tinggal di UPT lampung dengan jumlah sampel 33 orang lansia, memberikan hasil yang selaras yaitu penurunan tingkat depresi dengan nilai signifikasi $P$ value 0,00 (Rahma, 2017). Perubahan nilai pre test 19.16 dengan ratarata post test 10.36 juga terbukti pada hasil studi yang dilaksanakan di RSJD Dr. Amino Gondohutomo Semarang dengan pasien isolasi sosial menyajikan nilai uji beda paired sampel t-test $\mathrm{p}=0.00$ dan t-hitung 10.19 ( Rusanto, 2012)

Semakin spesifik genre musik, maka semakin baik untuk bisa dijadikan terapi untuk Kesehatan ( Leubner, 2017), sehingga musik yang familiar dan lebih spesifik dan dimengerti baik lirik atau familiar terhadap ritme lebih disaranka untuk menjadi sebuah terapi, seperti musik dangdut yang digunakan pada penelitian ini. Rekomendasi musik sebagai terapi juga didukung oleh beberapa literatur yang meneliti pengaruh musik terhadap depresi dengan mengkombinasikan dengan standar perawatan biasanya ( Therapy as Usual/TAU) (Maratos, 2008).

\section{KESIMPULAN}

Terapi Musik dangdut memiliki dampak yang bermakna secara statistik pada skor depresi kelompok orang dengan skizoprenia di RSJD. Dr Ariz Zainudin Surakarta.

\section{DAFTAR PUSTAKA}

Kemenkes, R. I. (2018). Hasil utama RISKESDAS 2018. Online) http://www. depkes. go. id/resources/download/infoterkini/materi_rakorpop_2018/Hasil\% 20Riskesdas, 2018.
Lerik, M. D. C., \& Prawitasari, J. E. (2005). Pengaruh Terapi Musik Terhadap Depresi di Antara Mahasiswa $=$ The Effect of Music Therapy on Depression Among Students. Sosiosains, 18(2005).

Leubner, D., \& Hinterberger, T. (2017). Reviewing the effectiveness of music interventions in treating depression. Frontiers in psychology, 8 , 1109.

Lewerissa, S. S., Yakobus, S., \& Titaley, C. R. (2019). Pengaruh Terapi Musik Klasik Terhadap Perubahan Gejala Dan Fungsi Pada Pasien Rawat Inap Skizofrenia Di Rumah Sakit Khusus Daerah Provinsi Maluku. PAMERI: Pattimura Medical Review, 1(2), 31-44.

Maratos, A., Gold, C., Wang, X., \& Crawford, M. (2008). Music therapy for depression. Cochrane database of systematic reviews, (1).

Marzuki, M. B., \& Lestari, P. (2018). Pengaruh Terapi Musik Klasik Terhadap Tingkat Depresi pada Lansia di Unit Rehabilitasi Sosial Wening Wardoyo Kecamatan Ungaran Kabupaten Semarang. Jurnal Keperawatan Komunitas, 2(2), 81-86.

Purnama, D. M. W., \& Rahmanisa, S. (2016). Pengaruh Musik Klasik dalam Mengurangi Tingkat Kekambuhan Penderita Skizofrenia di Rumah. Jurnal Majority, 5(4), 50-54.

Purbowinoto, S. E. (2011). Pengaruh Terapi Musik terhadap Perubahan Tingkat Depresi pada Lansia di PSRW (Panti Sosial Tresna Wredha) Unit Budi Luhur, Kasongan, Bantul Yogyakarta.

Rahma, P. E., Sulastri, S., \& Rohayati, R. (2017). Pengaruh Terapi Musik 
Terhadap Tingkat Depresi Pada Lansia. Jurnal Ilmiah Keperawatan Sai Betik, 9(2), 151-157.

Rusanto, A. F., Nugroho, A., \& Nurullita, U. (2012). Pengaruh Terapi Musik Populer Terhadap Tingkat Depresi Pasien Isolasi Sosial di Rumah Sakit Jiwa Daerah Dr. Amino Gondohutomo Semarang. Karya Ilmiah.
Setiawan, I. Y. 2019 . Gambaran program kesehatan jiwa: penanganan ODGJ pasung di kabupaten Cilacap. Berita Kedokteran Masyarakat, 35(4), 7-7.

Taroreh, R. M. (2004). Pengaruh Terapi Musik terhadap Gangguan Perilaku Apati pada Penderita Skizofrenia. 